\title{
Technical Appliance in E-Learning: Student's Perception on the Usage of Online Learning
}

\author{
$\underline{\text { doi:10.3991/ijet.v5i2.1145 }}$ \\ Issham Ismail, Siti Sarah Mohd. Johari and Rozhan M. Idrus \\ Universiti Sains Malaysia, Penang, Malaysia
}

\begin{abstract}
The purpose of this study was to gain insights into the student's perception on the usage of technical appliances in online learning. The study was conducted in the Universiti Sains Malaysia (USM) based on the sample of 1084 distance learners with the experiences of using the E-learning Portal in their distance education academic programme courses. The students were surveyed on the participation needs based on respondent's personal background, such as age, gender, ethnic groups, education streams and year-ofstudy. The results showed even though most of the students felt uncertain about the technical appliances in the $E$ learning Portal, the study illustrated the true nature of the student's perceptions with respect to the functionality and effectiveness of technical appliance in the E-learning Portal. This research is essential to elucidate the functions of technical appliances in facilitating the process of learning through the portal.
\end{abstract}

Index Terms-Distance education, e-learning portal, student perception, technical appliance

\section{INTRODUCTION}

Education is highly valued and cherished in Malaysia, as well as in many other countries since a lot of efforts are implemented in order to maintain, sustain and continuously improve as they want new programmes and plans to be created and instituted [1]. For many, access to higher education is especially critical and according to Dzakira and Idrus, distance education is one of the most cost effective ways of democratising education and giving access to life long learning [1].

As new technologies are proliferating through various aspects of everyday life, Universiti Sains Malaysia (USM) has heavily integrated IT in its delivery system and has become the leading higher learning institutions in Malaysia offering distance education [1].

The E-learning Portal has become a medium of teaching and learning in the USM Distance Learning Programme through a home-grown electronic portal in 2003 followed by a full migration into Moodle in 2005. Moodle is a software package known to produce Internet-based courses and web sites as it is a global development project designed to support a social constructionist framework of education. The portal has become an essential tool for both administrative and learning support (such as forum, chat and lecture notes), and it is being used actively by both lecturers and students. The idea behind developing this portal was to set up a one stop center for references for the purpose of e-learning such as articles, books, software, expert's advices, and consultation provided by supervisors or lecturers.
Dagger et al. reported that during the process of creating adaptive and non-adaptive courses by using a supportbased framework, there are a number of requirements that must be realised [2]. One of those requirements is technical needs. These needs reflected that learner's awareness of technical appliances has become important determinants of E-Learning Portal.

In developing a framework for the evaluation of elearning, the variables impacting on the quality of elearning were recognised [3]. There were five groups of variables identified, namely, individual learner variables, learning environment variables, contextual variables, technology variables and pedagogic variables.

This study focused on the technical elements in online learning and relayed on the technology. According to Attwell, the technology variables in the framework are one of the crucial foundation which gives impact on the quality of e-learning [3]. These variables are technical supports which includes hardware, software, connectivity, and the media and as well as mode of delivery. They recognised that each variable would affect the other; thus it was possible to develop the combination of differentiating variables and individual variables as well as to identify what should be the key factors in any e-learning development policy.

The e-learning policy should ensure learners have access to computers and other hardware and at the same time they are provided with technical support for hardware systems. Furthermore, it should also promote the development of different types of e-learning software to support different learning processes. Thus, E-learning should ensure sufficient bandwidth is available to support the type of online learning applications being used and to ensure e- learners have opportunities in gaining valuable experiences in conjunction with their e-learning. With each new generation, more and more features and technical appliances are being added to the e-learning repertoire and this study was conducted to examine the student's perceptions on technical appliances in E-learning Portal in USM.

\section{LITERATURE REVIEW}

There were many studies exploring learner's perspectives of online learning particularly in addressing the strengths and weaknesses (see Table I). However, very few literatures are related to technical elements and appliances in online learning.

There were a few studies reported one of the strengths of online learning is flexibility [4] [5]. In Petrides's study, the participants reported it was easier to work in collaborative groups in an online course without rearranging eve- 
ryone's schedule as one might do in a traditional face-toface course [4]. In addition to flexibility with time, choices related to the learning experience were also reported as positive since Chizmar and Walbert indicated that the ability to freely pick and choose from the menu of diverse learning experiences enabled the participants to find the approaches that best fit the way they learn [6].

Another advantage identified in the online learning literature is convenience [7] [8] [9]. In Poole's study of student participation in a discussion-oriented online course, the results indicated that students participated in online discussions at times most convenient to them [8]. Poole also found that students mostly accessed course materials from their home computers, which is the most convenient place for them. Murphy and Collins found similar results in their study of communication conventions in instructional electronic chats whereby participants indicated they read and responded to comments in online discussions at times convenient to them (e.g., early morning, late evening) [9].

Other than that, participants in Song et al's study indicated that the design of the course (82\%), comfortable with online technologies (82\%), and time management (80\%) were the major influencing components in the success of an online course [7]. Brown and Voltz also agreed education materials that have been effectively designed will facilitate the achievement of desired online learning outcomes for students [12].

Besides, online learning encouraged participants to give thoughtful and responsible comments [4] [6] [11]. Petrides reported participant tended to think more deeply about the subject areas when responding in writing as compared to verbal version [4]. According to Vonderwell, online learning allowed the participants to write carefully about their ideas [11].

However, there were several weaknesses related to online learning. Delay in responses is reported as one of the weaknesses [4] [7] [10] [11]. Petrides's study showed some participants reported that they felt a lack of immediacy in responses in the online context in comparison to what could typically occur in a structured face-to-face class discussion [4]. Hara and Kling also agreed delay of responses occurred in online learning as the students felt lack of immediacy in getting responses from the instructor and as a result, they felt frustrated [10]. Another weakness identified in online learning studies was perceived level of expertise since the participants are reported to be skeptical of their peer's expertise [4].

Furthermore, Song et al's also found participants who were less satisfied with online learning which they felt a lack of community within the online environment, having difficulty understanding the goals/objectives of the course and facing technical problems as a barrier [7]. They claimed the biggest challenge reported by the participants was technical problems [7]. The study also showed that technical problems were a challenge to participants who are more satisfied with online learning and those that were equally satisfied with online learning as compared to traditional classroom learning.

Most of the literatures highlighted the strengths and weaknesses of online learning, however very few of them argue on the technical issues in online learning. This study has attempted to gain insights into the student's perception
TABLE I.

STRENGTHS AND WEAKNESSES IN ONLINE LEARNING

\begin{tabular}{|c|c|c|}
\hline Studies & Strengths & Weaknesses \\
\hline $\begin{array}{l}\text { Murphy } \\
\text { and Collins } \\
\text { [9] }\end{array}$ & $\begin{array}{l}\text { Convenience - Participants } \\
\text { indicated they can read and } \\
\text { respond to comments in } \\
\text { online education at times } \\
\text { convenient to them. }\end{array}$ & \\
\hline $\begin{array}{l}\text { Hara and } \\
\text { Kling [10] }\end{array}$ & & $\begin{array}{l}\text { Delay in responses - } \\
\text { Students felt lack of } \\
\text { immediacy in getting } \\
\text { responses back from the } \\
\text { instructor }\end{array}$ \\
\hline $\begin{array}{l}\text { Chizmar } \\
\text { and Walbert } \\
\text { [6] }\end{array}$ & $\begin{array}{l}\text { - Thoughtful and responsi- } \\
\text { ble comments. } \\
\text {-Flexibility }\end{array}$ & \\
\hline Poole [8] & $\begin{array}{l}\text { Convenience - students } \\
\text { participated in online dis- } \\
\text { cussions at times most } \\
\text { convenient to them. }\end{array}$ & \\
\hline Schrum [5] & -Flexibility & \\
\hline Petrides [4] & $\begin{array}{l}\text {-Flexibility } \\
\text {-Thoughtful and responsible } \\
\text { comments }\end{array}$ & $\begin{array}{l}\text {-Delay in responses } \\
\text {-Skeptic with level of } \\
\text { expertise }\end{array}$ \\
\hline $\begin{array}{l}\text { Vonderwell } \\
{[11]}\end{array}$ & $\begin{array}{l}\text {-Thoughtful and responsible } \\
\text { comments }\end{array}$ & $\begin{array}{l}\text {-Delay in responses } \\
\text {-Lack of community or } \\
\text { feelings of isolation }\end{array}$ \\
\hline Song et al [7] & $\begin{array}{l}\text {-Convenience } \\
\text {-Design of the course } \\
\text {-Comfort with technologies } \\
\text {-Time management }\end{array}$ & $\begin{array}{l}\text {-Delay in responses } \\
\text {-Technical problems } \\
\text {-Lack of community } \\
\text {-Difficulties in under- } \\
\text { standing the goals of the } \\
\text { course }\end{array}$ \\
\hline $\begin{array}{l}\text { Brown and } \\
\text { Voltz [12] }\end{array}$ & Design of the course & \\
\hline $\begin{array}{l}\text { Serce and } \\
\text { Yildirim [13] }\end{array}$ & & $\begin{array}{l}\text { Lack of diversity of } \\
\text { tools }\end{array}$ \\
\hline $\begin{array}{l}\text { Gilbert et al } \\
\text { [14] }\end{array}$ & & $\begin{array}{l}\text { The usability and ro- } \\
\text { bustness of the delivery } \\
\text { platform is not adequate } \\
\text { and can be very slow }\end{array}$ \\
\hline
\end{tabular}

on the usage of online learning and to observe if there's any pertinent technical issue arising.

\section{METHOD}

The current study explores student's perception on the usage of technical appliances on online learning. The research samples are based on 1084 Universiti Sains Malaysia (USM) distance learners, targeted from the School of Distance Education.

\section{A. Participants}

The number of females responding to the questionnaire slightly outnumbered males, with $53 \%$ and $47 \%$ male. As for ethnic structure, $70 \%$ of the respondents were Malay, $21 \%$ were Indian, $5 \%$ were Chinese and the rest were from other ethnic group. About $32 \%$ of the respondents reported that they were Sciences majors, $31 \%$ were from Management, $29 \%$ were from Social Sciences and $8 \%$ were from Arts.

The age range in the sample was between 20 and 50 years old. The study found out the majority of the students was between 20 to 40 years old and it was noted that this age group prefers to pursue their studies in Distance Edu- 
cation. About $42 \%$ of the respondents obtained 2.50 to 2.99 of current Cumulative Grade Point Average, which indicated most of students are able to preserve their studies by using this system of information technology particularly by using e-learning tools.

\section{B. Instruments}

This survey was constructed based on self-administered questionnaire which solicited student's perceptions on the various aspects of technical appliance of e-learning to facilitate their learning. The questionnaire was designed and validated by expertise from School of Distance Education. The questionnaire contains closed questions pertaining how student perceives technical appliances while they are using E-Learning Portal. There were three positive statements inserted while others were negative statements. A five-point Likert scale was utilised as 1 for strongly disagree (SD) and 5 for strongly agree (SA). Responses on statements covering these aspects are summarised in Table II under each respective statement.

The questionnaires were distributed to USM students of 2007/2008 sessions in the School of Distance Education. Respondents were selected randomly and this sample was chosen because it represents a group of individuals who have experienced the use of e-learning portal and at the same time had accessed resources of e-learning content. The distribution and collection of questionnaires from respondents were conducted within the annual residential intensive course. At the end of the survey, 1084 questionnaires were returned.

\section{Data Analysis}

The questionnaires consist of two sections. Section A covers the respondent's personal background, such as age, gender, ethnic group, education streams and year-of-study. Section B contains questions on the students' receptiveness and satisfaction level of IT system usage, such as their level of experience of e-learning portal and its content, the technical and the design of the portal, the learning activities, the improvement needed, and the effectiveness of using IT system in School of Distance Education.

The data was analysed by utilising the Statistical Package for Social Science (SPSS) Version 12.0 based on frequency and percentage distribution. Frequencies were run to determine the distribution of the demographic profile and IT usage and experience. The survey comes out with 0.78 Cronbach alphas which indicated there was consistency reliability in the instruments. In response to those statements, the survey has proved that there is no significant difference from gender, education streams, ethnicity and current CGPA.

\section{RESUltS AND DisCUSSION}

As shown in Table II, the majority of the responses indicated that technical appliances had a positive effect on the use of E-Learning Portal for distance education learners although most of the students felt E-Learning Portal is quite challenging.

When the respondents were asked about the technical components that they should own, the negative statements were used. Based on the survey that was carried out, we can learn that $90 \%$ of the samples own a computer of their own. In addition, $81.6 \%$ claimed that they have access to internet and only $7.8 \%$ declared they lack in Internet surfing skills. Young suggested that rich learning activities allow students to learn with computers rather than from computers [15]. Therefore, in order to ensure the portal serves its purpose and at the same time to determine the success of this programme, learners must have access to computers and sufficient quality and quantity of other hardware to meet their e-learning needs. For that reason, to make this programme effective it is important to ensure the learners are one hundred per cent own a computer and got access to the Internet.

E-learning should support measures to improve the quality of the ICT learning environment [3]. The results exhibited thar there were a quite number of the students agreed about facing the difficulties in accessing the ELearning Portal (21.9\%) and $59 \%$ of respondents strongly disagreed or disagreed that they are not familiar with E-Learning Portal tools. It shows that students felt irritated in accessing the E-Learning Portal and still many students are not savvy with the E-Learning Portal tools. This is supported by Chizmar and Walbert [6] that the ability to freely pick and choose from the menu of diverse learning experiences enabled the participants to find the approaches that best fit the way they learn. In addition, according to Serce and Yildirim, it is essential to enrich the learning environment with variety of tools, which support different instructional strategies such as reviews [13].

All in all the students felt E-Learning portal is user friendly which makes up to $52.1 \%$, and found that $45.6 \%$ agreed/strongly agreed that they can use E-Learning Portal easily. This can be related to Song et al [7] and Brown \& Voltz [12] study since it was indicated that the design of the course was the major influencing component in the success of an online course. However, the reasons the respondents felt quite challenging to use E-Learning Portal probably because downloading course materials is very time consuming and sometimes failed.

Technically, the respondents claimed they did not have any problem to log in E-Learning Portal because only $18.8 \%$ declared they were having problem to log in the portal. More than half of the students (51.6\%) felt that user manual really helped them. However, some of them agreed $(24.1 \%)$ that downloading learning material always failed. These results are parallel to Song et al [7] and Gilbert et al [14] as the biggest challenge reported by the study was technical problems and the usability and robustness of the delivery platform is not adequate and can be very slow. With respect to downloading learning material, the portal should promote mechanisms to improve stability and robustness of overall systems to minimise disruption to e-learning.

The results showed some of the students were facing the difficulties in contacting E-Learning Portal administration (20.7\%) while facing technical problems and about 42 $\%$ of them were agreed that downloading course material is taking too much time. According to Song et al [7] time management was one of the major components influencing the success of an online course. However, since almost half of the students agreed on the plenty of time to download the course material, it was not very encouraging. These results reflected that this portal could be a failure if these two crucial technical elements were overlooked when implementing E-Learning Portal to distance learners. The system should support different options in providing connectivity and bandwidth. 
TABLE II.

STUDENT’s PERCEPTIONS OF TECHNICAL APPLIANCE

\begin{tabular}{|l|c|c|c|}
\multicolumn{1}{|c|}{ Statement (N=1084) } & $\begin{array}{c}\text { Agree/ } \\
\text { Strongly } \\
\text { Agree }\end{array}$ & Mean & Std. Dev. \\
\hline I don't have a computer & $9.4 \%$ & 1.61 & 1.108 \\
\hline I have no Internet access & $18.4 \%$ & 2.01 & 1.363 \\
\hline $\begin{array}{l}\text { I'm unskilled in surfing the } \\
\text { Internet }\end{array}$ & $7.8 \%$ & 1.93 & 1.061 \\
\hline $\begin{array}{l}\text { I have internet access but face } \\
\text { difficulties in accessing E- } \\
\text { Learning Portal }\end{array}$ & $21.9 \%$ & 2.51 & 1.188 \\
\hline $\begin{array}{l}\text { I'm not familiar with E-Learning } \\
\text { Portal tools }\end{array}$ & $13 \%$ & 2.27 & 1.108 \\
\hline E-Learning Portal is user friendly & $52.1 \%$ & 3.56 & 1.324 \\
\hline I can use E-Learning Portal easily & $45.6 \%$ & 3.4 & 1.033 \\
\hline $\begin{array}{l}\text { I have trouble to log-in E- } \\
\text { Learning Portal }\end{array}$ & $18.8 \%$ & 2.48 & 1.132 \\
\hline \begin{tabular}{l} 
User manual really helps me \\
\hline $\begin{array}{l}\text { Downloading learning materials is } \\
\text { always failed }\end{array}$
\end{tabular} & $24.1 \%$ & 2.80 & 1.087 \\
\hline $\begin{array}{l}\text { Difficulties in contacting E- } \\
\text { Learning Portal administration } \\
\text { while facing technical problems }\end{array}$ & $20.7 \%$ & 2.79 & 1.028 \\
\hline $\begin{array}{l}\text { Downloading course material is } \\
\text { taking too much time }\end{array}$ & $42.4 \%$ & 3.28 & 1.104 \\
\hline
\end{tabular}

Albeit most of the students felt quite uncertain about the technical appliance in E-Learning Portal, the study reflects the student's awareness and experiences of using the portal, technically.

\section{CONCLUSION}

This study demonstrated that many respondents perceived that technical appliance was important and essential in the successful implementation of the E-Learning Portal. The analysis showed there was no problem to put e-learning into practice if the students own a computer and have access to the Internet. Although most of the students were skillful in surfing the Internet, they did express the dissatisfaction on the unfamiliarity of the E-Learning Portal tools. The biggest technical issue arose when downloading the course materials through the Portal was very time consuming. This could lead to the students' feeling frustrated and for that reason, half of them declared that the usage of this Portal was quite challenging. Therefore, attention should be given to the successful download and downloading-time of the learning materials in E-learning Portal. More investigation needs to be carried out of how we could improve the Portal to include friendlier design and recover the robustness of the delivery platform. Besides that, research is also needed into how mobile learning might support those forms of e-learning to provide high quality collaborative, contextualise and active learning.

\section{ACKNOWLEDGMENT}

The authors would like to thank Universiti Sains Malaysia for the support under RU grant and USM Fellowship scheme.

\section{REFERENCES}

[1] Dzakira, H. \& Idrus, R.M. (2003). Teacher-Learner Interactions in Distance Education: A Case of two Malaysian Universities. Turkish Online Learning Journal of Distance Education TOJDE, 4(3), 1-15.

[2] Dagger, D., Wade, V. \& Conlan, O. (2004). A Framework for Developing Adaptive Personalised eLearning. In G. Richards (Ed.), Proceedings of World Conference on E-Learning in Corporate, Government, Healthcare, and Higher Education 2004 (pp. 2579-2587).

[3] Attwell, G., Evaluating E-learning: A Guide to the Evaluation of E-learning. (2006). Evaluate Europe Handbook Series, 2. Stanford: California..

[4] Petrides, L.A. (2002). Web-based technologies for distributed (or distance) learning: Creating learning-centered educational experiences in the higher education classroom. International Journal of Instructional Media, 29(1), 69-77.

[5] Schrum, L. (2002). Oh, what wonders you will see: Distance education past, present, and future. Learning and Leading with. Technology, 30(3), 6-920-21.

[6] Chizmar, J. F., \& Walbert, M. S. (1999). Web-based learning environments guided by principles of good teaching practice. Journal of Economic Education, 248-264.

[7] Song, L., Singleton, E., Hill, J., \& Koh, M. (2004). Improving online learning: Student perceptions of useful and challenging characteristics. The Internet and Higher Education, 7(1), 59-70. doi:10.1016/j.iheduc.2003.11.003

[8] Poole, D. M. (2000). Student participation in a discussion-oriented online course: A case study. Journal of Research on. Computing in Education, 33(2), 162-177.

[9] Murphy, K. L., \& Collins, M. P. (1997). Communication conventions in instructional electronic chats. First Monday, 2(11), 27-33.

[10] Hara, N., \& Kling, R. (1999). Students' frustrations with a webbased distance education course. First Monday, 4(12), 3.

[11] Vonderwell, S., Liang, X., \& Alderman, K. (2007). Asynchronous discussions and assessment in online learning. Journal of Research on Technology in Education, 39(3), 309. International Society for Technology in Education. Retrieved from http://scholar.google.com/scholar?hl=en\&btnG=Search\&q=intitle: Asynchronous+Discussions+and+Assessment+in+Online+Learning \#0.

[12] Brown, A., \& Voltz, B. (2005). Elements of effective e-learning design. International Review of Research in Open and Distance Learning, 6(1), 1-9. Retrieved from http://scholar.google.com/scholar?hl=en\&btnG=Search\&q=intitle: Elements+of+Effective+e-Learning+Design\#0.

[13] Serce, F., \& Yildirim, S. (2006). A web-based synchronous collaborative review tool: a case study of an on-line graduate course. Journal of Educational Technology and Society, 9(2), 166. Cite seer. Retrieved from http://scholar.google.com/scholar?hl=en\& btnG=Search\&q=intitle:A+web-

based+synchronous+collaborative+review+tool:+a+case+study+of + an+on-line+graduate+course\#0.

[14] Gilbert, J., Morton, S., \& Rowley, J. (2007). E-Learning: The student experience. British Journal of Educational Technology, 38(4), 560-573. Blackwell Publishing Ltd, 9600 Garsington Road. Retrieved from http://scholar.google.com/scholar?hl=en\&btnG= Search\&q=intitle:e-Learning:+The+student+experience\#0.

[15] Young, L. (2003). Bridging Theory and Practice: Developing guidelines to facilitate the design of computer-based learning environments. Canadian Journal of Learning and Technology, 23(3). Retrieved from: http://www.cjlt.ca/content/vol29.3/cjlt29- 3 art 4.html

\section{AUTHORS}

Issham Ismail is with the School of Distance Education, Universiti Sains Malaysia, Minden, Pulau Pinang, 11800 Malaysia (e-mail: issham@ usm.my).

Rozhan M. Idrus, is a Professor of Open and Distance Learning \& Technogogy in the School of Distance Education, Universiti Sains Malaysia, Minden, Pulau Pinang, 
11800 Malaysia. He specialises in Open and Distance Learning Interactive Technologies and online pedagogies and technogogy (e-mail: rozhan@usm.my).

Siti Sarah Mohd Johari is a student under the School of Distance Education, Universiti Sains Malaysia, Minden, Pulau Pinang, 11800 Malaysia, and currently further- ing her study in Masters of Education Technology (email: sitisarahmjohari@gmail.com).

This work was supported in part by the Universiti Sains Malaysia under RU Grant 1001/PJJAUH/817015

Manuscript received November $18^{\text {th }}$ 2009.Published as resubmitted by the authors May $24^{\text {th }} 2010$. 